Pesq. Vet. Bras. 38(2):309-314, fevereiro 2018

\title{
Detection of natural occurrence of Tritrichomonas foetus in cats in Araçatuba, São Paulo, Brazil ${ }^{1}$
}

\author{
Roberta P. Duarte ${ }^{2}$, Paulo Ricardo D.A. Rocha², Alex A. Nakamura², \\ Rafael S. Cipriano ${ }^{3}$, Milena A. Viol ${ }^{4}$, Guilherme D. Melo ${ }^{5}$, \\ Marcelo V. Meireles ${ }^{2}$ and Gisele F. Machado ${ }^{2 *}$
}

\begin{abstract}
Duarte R.P., Rocha P.R.D.A., Nakamura A.A., Cipriano R.S., Viol M.A., Melo G.D., Meireles M.V. \& Machado G.F. 2018. Detection of natural occurrence of Tritrichomonas foetus in cats in Araçatuba, São Paulo, Brazil. Pesquisa Veterinária Brasileira 38(2):309-314. Faculdade de Medicina Veterinária, Universidade Estadual Paulista "Julio de Mesquita Filho, Campus de Araçatuba, Rua Clóvis Pestana 793, Araçatuba, SP 16050-680, Brazil. E-mail: giselem@fmva.unesp.br

The aim of this study was to investigate the occurrence of Tritrichomonas foetus in cats in the area surrounding the city of Araçatuba municipality, State of São Paulo, Brazil. Fecal samples from 129 cats were collected by rectal flush technique. It was compared two diagnosis methods, direct examination of feces and PCR. The presence of T. foetus DNA was verified using PCR by amplification of 347-bp fragment from the primers TFR3 and TFR4 and amplicons of positive cases were sequenced. Statistical analyses were performed investigating the associations between T. foetus infection with gender, age, breed, presence of diarrhea and/or history of diarrhea, previous treatment, lifestyle, origin, environment, and co-infection. T. foetus was observed in one sample $(\mathrm{n}=129)$ by direct microscopic examination of feces while PCR was positive in five samples (3.9\%). Giardia species and Cryptosporidium species co-infection was also observed. Statistical analyses showed no significant associations between T. foetus infection and all listed factors, although most positive cats were asymptomatic and lived in multi-cat household. The isolates of T. foetus showed $100 \%$ identical sequences with other T. foetus isolates from cats around the world. So, the occurrence of $T$. foetus was confirmed in cats in Araçatuba city (Brazil). This parasite must be considered as a differential diagnosis in cats with diarrhea and also in asymptomatic carriers as source of infection in multi-cat environments.

INDEX TERMS: Tritrichomonas foetus, cats, diarrhea, polymerase chain reaction, PCR, genetic sequencing, parasitoses.
\end{abstract}

RESUMO.- [Detecção da ocorrência natural de Tritrichomonas foetus em gatos em Araçatuba, São Paulo.] 0 objetivo deste estudo foi investigar a ocorrência de Tritrichomonas foetus

\footnotetext{
${ }^{1}$ Received on November 3, 2016.

Accepted for publication on December 22, 2016.

${ }^{2}$ Programa de Pós-Graduação em Ciência Animal, Faculdade de Medicina Veterinária de Araçatuba, Universidade Estadual Paulista "Julio de Mesquita Filho" (Unesp), Campus de Araçatuba, Rua Clóvis Pestana 793, Araçatuba, SP 16050-680, Brazil. *Corresponding author: giselem@fmva.unesp.br

${ }^{3}$ Centro de Controle de Zoonoses, Rua Dr. Luís de Almeida 145, Araçatuba, SP 16052-470.

${ }^{4}$ Centro de Diagnóstico Laboratorial Veterinário, Rua Almirante Barroso 315, Araçatuba, SP 16015-085.

${ }^{5}$ InstitutPasteur, Laboratoire des Processus Infectieuxà Trypanosomatidés, 28 rue du Dr Roux, 75015, Île-de-France, Paris, France.
}

em gatos na região do município de Araçatuba, SP, Brasil. Foram coletadas amostras fecais de 129 gatos através da técnica de lavado retal. Dois métodos diagnósticos foram comparados, o exame direto das fezes e a PCR. A presença de DNA de T. foetus foi verificada por meio da PCR através da amplificação de 347 pares de bases a partir dos iniciadores específicos TFR3 e TFR4. Posteriormente, os resultados amplificados das amostras positivas foram sequenciadas. Também foi feita análise estatística a fim de investigar a correlação entre infecção por T. foetus e sexo, idade, raça, presença e/ou histórico de diarreia, tratamento prévio, coinfecção, estilo de vida, origem e tipo de ambiente. 0 protozoário pôde ser observado em uma amostra através do exame direto das fezes e à PCR foram detectadas cinco amostras positivas (3.9\%). Foram detectadas coinfecções por 
Giardia spp. e Cryptosporidium spp. Não foram observadas correlações entre infecção por T. foetus e todos os fatores listados anteriormente, embora a maioria dos felinos positivos fossem assintomáticos e vivessem em ambientes multigatos. 0 resultado do sequenciamento genético dos isolados das amostras positivas mostrou $100 \%$ de similaridade com outros isolados de felinos no mundo. Assim, a ocorrência de T. foetus foi confirmada em gatos em Araçatuba, São Paulo, Brasil. Sendo assim, o parasito deve considerado como diagnóstico diferencial em gatos com diarreia assim como em portadores assintomáticos como fontes de infecção em ambientes multigatos.

TERMOS DE INDEXAÇÃO: Tritrichomonas foetus, felinos, diarreia, reação em cadeia da polimerase, PCR, sequenciamento genético, parasitoses.

\section{INTRODUCTION}

Tritrichomonas foetus is a protozoan best known for causing sexually transmitted disease in cattle (BonDurant 1997). Likewise, T. foetus would be a synonym of Tritrichomonas suis (Doi et al. 2012). However, in cats T. foetus colonizes the colon causing chronic large bowel diarrhea and is transmitted by the fecal-oral route (Levy et al. 2003, Tolbert \& Gookin 2009, Gruffydd-Jones et al. 2013). But not all infections by T. foetus in cats are associated with clinical signs, since diarrhea may resolve temporarily without treatment (Tolbert \& Gookin 2009, Gruffydd-Jones et al. 2013).

Young cats with one year old or less seen to be more susceptible to T. foetus infection, whereas older cats are generally asymptomatic (Levy et al. 2003, Tolbert \& Gookin 2009). Other risk factor, also the most important, is multi-cat household (Gruffydd-Jones et al. 2013, Yao \& Köster 2015), since the trophozoites do not persist for a long time out in the environment and cats become infected probably through close contact, specially by mutual grooming (Tolbert \& Gookin 2009, Gruffydd-Jones et al. 2013).

Comparative analysis of molecular markers suggests the differentiation of "cat genotype" and "cattle genotype" of T. foetus (Slapeta et al. 2010). Cats that were experimentally infected with T. foetus isolates from heifers and heifers that were infected with $T$. foetus isolates from cats showed no similarities on the infectivity and pathogenicity (Stockdale et al. 2007, Stockdale et al. 2008). A recent study suggested that T. foetus isolated from feces of different cats may belong to new specie, which would justify the use of a new name, Tritrichomonas blagburni (Walden et al. 2013).

The occurrence of $T$. foetus in cats has been cited as worldwide distribution (Yao \& Köster 2015). It has been reported in several countries such as United Kingdom (Gunn-Moore et al. 2007), The United States of America (Stockdale et al. 2009), Switzerland (Frey et al. 2009), Italy (Holliday et al. 2009), Australia (Bell et al. 2010), South Korea (Lim et al. 2010), New Zealand (Kingsbury et al. 2010), Greece (Xenoulis et al. 2010), Germany (Kuehner et al. 2011), Spain (Miró et al. 2011), Norway (Tysnes et al. 2011), Japan (Doi et al. 2012), Canada (Hosein et al. 2013) and France (Profizi et al. 2013). Due to the increasing interest in this protozoan in feline medicine, the current study was designed to investigate the occurrence of T. foetus in Brazilian cats using direct examination of feces, PCR, and further genetic sequencing. Additionally, to investigate the associations between $T$. foetus infection and some risk factors such as gender, age, breed, presence and/or history of diarrhea, previous treatment, co-infection, lifestyle, origin and multi-cat household.

\section{MATERIALS AND METHODS}

Data collection, fecal samples and direct feces examination. Data about the cats were obtained by asking the owners or caretakers and approval was ensured by a written consent before samples collection. Fecal samples were collected from 129 cats chosen by convenience living in the area surrounding the city of Araçatuba, São Paulo, Brazil. Kittens under two months of age were excluded from the study. The domestic shorthairs were classified as mixed breed by the absence of pedigree. Fecal samples were collected by rectal flush technique consisting in infusion of $10 \mathrm{~mL}$ of $0.9 \%$ saline solution with the usage of a syringe attached to a urethral probe $\mathrm{n}$-8 (https://cvm.ncsu.edu/research/labs/ clinical-sciences/tfoetus). Within six hours (Hale et al. 2009), the aspirated fluid was placed in a conical tube and stored at room temperature for 15 minutes for precipitation of its content. A precipitate drop of each sample was examined under a coverslip at $100 \mathrm{x}$ and $400 \mathrm{x}$ magnification by a light microscopy direct examination (Tolbert \& Gookin 2009, Gruffydd-Jones et al. 2013). Subsequently, DNA was extracted using the ZR Fecal DNA Kit ${ }^{\circledR}$, Zymo Research, Orange, CA, USA, and so the extracted DNA was stored at $-20^{\circ} \mathrm{C}$ for PCR.

PCR for Tritrichomonas foetus. A total volume of $25 \mu \mathrm{L}$ for each reaction mixture was prepared with $500 \mathrm{nM}$ of primers TFR3 and TFR4 (Felleisen et al. 1998); 0.2mM deoxynucleotide (A,C,T,G) solution,, Deoxinucleotide (dNTP) Mix, Sigma $^{\circledR}$, Saint Louis, Missouri 63103, USA; 0.5U Taq DNA polimerase, Platinum $^{\circledR}$, Invitrogen ${ }^{\mathrm{TM}}$, by Life technologies ${ }^{\mathrm{TM}}$; $2 \mathrm{mM} \mathrm{MgCl}_{2} ; 2.5 \mu \mathrm{L}$ buffer $10 \mathrm{x} ; 2 \mu \mathrm{L}$ of extracted DNA sample; and the remaining volume was completed with ultrapure water' Sigma ${ }^{\circledR}$, SIGMA-ALDRICH, UK. DNA amplification followed the conditions established by Gookin et al. (2002) with minor modifications in a thermal cycler' Mastercycler eppendorf, Realplex ${ }^{2}$ : initial denaturation at $94^{\circ} \mathrm{C}$ for 5 minutes, denaturation at $95^{\circ} \mathrm{C}$ for 30 seconds, annealing at $67^{\circ} \mathrm{C}$ for 30 seconds, extension at $72^{\circ} \mathrm{C}$ for 45 seconds, repeated for 50 cycles, followed by final extension at $72^{\circ} \mathrm{C}$ for 5 minutes. The positive control was commercially purchased, VetMAX ${ }^{\mathrm{TM}}$ T. foetus Control, Invitrogen ${ }^{\mathrm{TM}}$, by Life technologies ${ }^{\mathrm{TM}}$, and the negative control was ultrapure water. The presence of $T$. foetus DNA was verified by amplification of 347-bp fragment after electrophoresis on a $1.5 \%$ agarose gel and visualized by UV illumination.

PCR for Giardia species. A total volume of $25 \mu \mathrm{L}$ for each reaction mixture was prepared with 200nM of primers GDH1 and GDH4 (Homan et al. 1998); 0.2mM deoxynucleotide $(\mathrm{A}, \mathrm{C}, \mathrm{T}, \mathrm{G})$ solution; $0.5 \mathrm{U}$ Taq DNA polymerase; $2 \mathrm{mM} \mathrm{MgCl}_{2}$; $2.5 \mu \mathrm{L}$ buffer $10 \mathrm{x} ; 0.5 \mathrm{pmol} / \mu \mathrm{L}$ bovine serum albumin (BSA); $2.5 \mu \mathrm{L}$ of extracted DNA sample; and the remaining volume was completed with ultrapure water. DNA amplification followed the conditions established by Homan et al. (1998). The presence of Giardia DNA was verified by amplification of approximately 768-bp fragment.

Nested-PCR for Cryptosporidium species. Both primary and secondary reactions were prepared with $200 \mathrm{nM}$ of primers stablished by Xiao et al. (1999a, 2000); 0.2mM deoxynucleotide 
$(\mathrm{A}, \mathrm{C}, \mathrm{T}, \mathrm{G})$ solution; $0.5 \mathrm{U}$ Taq DNA polymerase; $2 \mathrm{mM} \mathrm{MgCl}_{2} ; 2.5 \mu \mathrm{L}$ buffer $10 \mathrm{x}$ and $2.5 \mu \mathrm{L}$ of extracted DNA sample. For primary reaction $0.5 \mu \mathrm{g} / \mu \mathrm{L}$ BSA was added. Remaining volume was completed with ultrapure water for a total volume of $25 \mu \mathrm{L}$ for each reaction mixture. DNA amplifications were done according to the following conditions: initial denaturation at $95^{\circ} \mathrm{C}$ for 3 minutes, denaturation at $95^{\circ} \mathrm{C}$ for 45 seconds, annealing at $55^{\circ} \mathrm{C}$ for 45 seconds, extension at $72^{\circ} \mathrm{C}$ for 1 minute, repeated for 39 cycles, followed by final extension at $72^{\circ} \mathrm{C}$ for 7 minutes. The presence of Cryptosporidium DNA was verified by final amplification of approximately 840-bp fragment.

Genetic sequencing. DNAs of positive cases were purified using the Gel Extraction Kit QIAquick ${ }^{\circledR}$, Quiagen ${ }^{\circledR}$, ICI Americas Inc. After DNAs quality and quantity were monitored, they were sequenced in both directions. The identities of the sequencings were checked using the BLAST ${ }^{\circledR}$ platform (Basic Local Alignment Search Tool). T. foetus sequences of positive cases were compared with the $T$. foetus bovine sequence, GenBank accession no. U85967 (Felleisen et al. 1998) and T. blagburni sequences, GenBank accession nos. EU569301 - EU569312 (Walden et al. 2013).

Statistical analysis. The correlation between both the diagnostic methods was determined using the kappa test (Conraths \& Schares 2006) and the $x^{2}$ test which was applied to evaluate the relationship between $T$. foetus infection and data about the cats, like gender, age, breed, presence and/or history of diarrhea, previous treatment, lifestyle, origin, environment, and co-infection.

\section{RESULTS}

Samples. Most cats were females ( $\mathrm{n}=83)$, adults, older than one year $(n=80)$, and mixed breed $(n=126) .19$ cats presented with diarrhea at the moment of collecting samples. Clinical history was available from 14 cats and 3 of them had already been treated for Giardia species. 77 cats lived in environments with more than one cat, only 7 alone, and of 45 information was not available. About the origin of the animals, 20 cats were from a rescue colony of an animal hoarder, 35 were from rescue colonies of non-governmental organizations, 17 were from a city shelter, 55 were from homes and 2 cats were from a Persian cattery. And about lifestyle, 64 cats lived exclusively indoor, 36 outdoor, both in urban areas, nine were from farms, and of 20 information was not available.

Diagnosis. By direct microscopic examination Tritrichomonas foetus was observed in one sample of feces and Giardia species was observed in another one. Toxocara species, Ancylostoma species, coccidia, Aelurostrongylus abstrusus and Dipylidium caninum infections were present in 19 cats and three of these cats had co-infection with two parasites, one with Ancylostoma species and coccidia, and two with Ancylostoma species and Dipylidium caninum.

PCR was positive for T. foetus in five cats (3.9\%), including positive sample by direct feces examination. Data about positive cats is available on Table 1. It was possible retrieve clinical history of just one positive cat. This cat lived exclusively indoors but had outdoor access in the past. His playmates were tested, and they were negative for T. foetus by PCR. One positive cat lived at a rescue colony of a hoarder and it was not possible to test all cats because new kittens arrived in the colony every day. One of the females was a stray cat and was caught by non-governmental organization for neutering. (Table 2)
Table 1. Comparison categorical data between PCR-positive and negative cats for Tritrichomonas foetus

\begin{tabular}{|c|c|c|c|}
\hline \multirow{2}{*}{ Risk factors } & \multicolumn{2}{|c|}{ PCR status } & \multirow{2}{*}{$P$ value } \\
\hline & Negative & Positive & \\
\hline \multicolumn{4}{|l|}{ Gender } \\
\hline Male & 44 & 2 & 0.8362 \\
\hline Female & 80 & 3 & \\
\hline \multicolumn{4}{|l|}{ Age } \\
\hline$<1$ year old & 48 & 1 & 0.3980 \\
\hline$\geq 1$ year old & 76 & 4 & \\
\hline \multicolumn{4}{|l|}{ Breed } \\
\hline Mixed breed & 121 & 5 & 0.7249 \\
\hline Purebred & 3 & 0 & \\
\hline \multicolumn{4}{|l|}{ Diarrhea } \\
\hline Yes & 18 & 1 & 0.7344 \\
\hline No & 106 & 4 & \\
\hline \multicolumn{4}{|l|}{ History of diarrhea } \\
\hline Yes & 13 & 1 & 0.6919 \\
\hline No & 23 & 1 & \\
\hline No information & 88 & 3 & \\
\hline \multicolumn{4}{|l|}{ Previous treatment } \\
\hline Yes & 3 & 0 & 0.7368 \\
\hline No & 53 & 2 & \\
\hline No information & 68 & 3 & \\
\hline \multicolumn{4}{|l|}{ Lifestyle } \\
\hline Indoor & 60 & 4 & - \\
\hline Outdoor & 35 & 1 & \\
\hline Rural & 9 & 0 & \\
\hline No information & 20 & 0 & \\
\hline \multicolumn{4}{|l|}{ Origin } \\
\hline Rescue colony of animal hoader & 19 & 1 & \\
\hline Rescue colony of NGOs & 34 & 1 & - \\
\hline Shelter & 17 & 0 & \\
\hline Home & 52 & 3 & \\
\hline Cattery & 2 & 0 & \\
\hline \multicolumn{4}{|l|}{ Multi-cat household } \\
\hline Yes & 73 & 4 & 0.5366 \\
\hline No & 7 & 0 & \\
\hline No information & 44 & 1 & \\
\hline \multicolumn{4}{|l|}{ Co-infection (other parasites) } \\
\hline Yes & 19 & 0 & - \\
\hline No & 110 & 0 & \\
\hline \multicolumn{4}{|l|}{ Giardia spp. co-infection } \\
\hline Yes & 60 & 4 & 0.1657 \\
\hline No & 64 & 1 & \\
\hline \multicolumn{4}{|l|}{ Cryptosporidium spp. co-infection } \\
\hline Yes & 19 & 1 & 0.7769 \\
\hline No & 105 & 4 & \\
\hline
\end{tabular}

- Impossibility of chi-square analysis.

Genetic sequencing. Sequencing of T. foetus isolated in the present study GenBank accession no. KX267765 showed $100 \%$ identity to homologous sequences of $T$. foetus isolated from other domestic cats in USA, AF466749 (Levy et al. 2003) and EU569309 (Stockdale et al. 2007, Walden et al. 2013); Switzerland, JN006994 (Reinmann et al. 2012); French, 
Table 2. Data about Tritrichomonas foetus PCR-positive cats

\begin{tabular}{|c|c|c|c|c|c|c|c|c|c|c|c|c|}
\hline Gender & Age & Breed & Diarrhea & $\begin{array}{l}\text { History of } \\
\text { Diarrhea }\end{array}$ & Treated & Environment & Multi-cat & $\begin{array}{c}\text { Other } \\
\text { positives }\end{array}$ & Origin & $\begin{array}{c}\text { Direct } \\
\text { examination } \\
\text { of feces }\end{array}$ & $\begin{array}{c}\text { PCR } \\
\text { Cryptosporidium } \\
\text { species }\end{array}$ & $\begin{array}{c}\text { PCR } \\
\text { Giardia } \\
\text { species }\end{array}$ \\
\hline Male & Adult & Mixed & No & No & No & Indoor & Yes & No & Hoarder & Negative & Negative & Negative \\
\hline Male & Adult & Mixed & No & Yes & No & Indoor & Yes & No & Home & Negative & Negative & Positive \\
\hline Female & Adult & Mixed & Yes & $*$ & $*$ & Indoor & Yes & $*$ & Home & Negative & Negative & Positive \\
\hline Female & Adult & Mixed & No & * & * & Indoor & Yes & $*$ & Home & T. foetus & Negative & Positive \\
\hline Female & Young & Mixed & No & $*$ & $*$ & Outdoor & $*$ & $*$ & NGO & Negative & Positive & Positive \\
\hline
\end{tabular}

* Information not avaliable.

JX960422 (Profizi et al. 2013); Norway, HM856630 (Tysnes et al. 2011) and EF165538 (Dahlgren et al. 2007); and Australia, GU170216 (Slapeta et al. 2010) and JX187000 (Slapeta et al. 2012). Furthermore, revealed a single nucleotide polymorphism ( $\mathrm{T}>\mathrm{C}$ ) when compared with $\mathrm{T}$. foetus isolated from cattle, similar to the findings previously described (Slapeta et al. 2010).

Four of T. foetus positive cats had co-infection with Giardia species and one with Cryptosporidium species. Sequencing of Giardia showed 99\% similarity with Giardia duodenalis Assemblage F, accession no. AB569373 (Suzuki et al. 2011) and sequencing of Cryptosporidium showed $100 \%$ similarity with C. felis, accession no. AF112575 (XIAO et al. 1999b).

Statistical analysis. Statistical analyses showed no significant associations between $T$. foetus infection, with gender, age, breed, presence of clinical signs, history of diarrhea, previous treatment, lifestyle, origin, multi-cat housing, and/or co-infection. According to the kappa test result, a fair agreement $(0,324)$ between diagnosis by direct examination of feces and PCR was found.

\section{DISCUSSION}

This is the first study about the occurrence of Tritrichomonas foetus in Brazilian cats and the occurrence was 3.9\%. Worldwide, the occurrence of this parasite has varied among countries. This variation may be due to two factors: 1) the cat population chosen to be studied; and 2) the diagnostic method (Gruffydd-Jones et al. 2013). It has been reported occurrence of $6.2 \%-15 / 241$ - in a study comparing the occurrence of T. foetus from cats sampled at cat shows, humane society and clinic (Hosein et al 2013), and also 82\% - 18/22 - in another study only from purebred cats sampled at cat shows (Kingsbury et al. 2010).

In the present study, it was included samples from cats of different populations, young and adult, with and without diarrhea, from various origins, and with diverse lifestyle. Although we did not find any correlation between $T$. foetus infection and all risk factors listed before, some of these relationships should be considered with caution, mainly due to the small number of representative samples of each population and lack of detailed information about some cats. For instance, T. foetus infection was detected in five cats and four of them were asymptomatic. Also, four cats have been living with more than one cat. Generally, T. foetus infection is associated as a result of multi-cat household, previously described as the main risk factor (Holliday et al. 2009, Bell et al. 2010, Kuehner et al. 2011). Simultaneously, the stress generated by the pressure of overcrowding, like in shelters and rescue colonies (Holliday et al. 2009), contributes to trigger episodes of diarrhea even in asymptomatic cats, which facilitates the dissemination of the parasite (Kuehner et al. 2011). In this way, screening of asymptomatic carriers, which can be a source of infection, should be considered in multi-cats environments (Gookin et al. 2001, Xenoulis et al. 2010, Miró et al. 2011).

Despite the high prevalence of this parasite in susceptible cat populations and although we did not find $T$. foetus positive cats from farms, this is the first study that also included a cat population from rural areas. The transmission route, if the cattle for the cat or the opposite, is an issue discussed by some authors (Stockdale et al. 2007, Stockdale et al. 2008, Slapeta et al. 2010, Slapeta et al. 2012, Reinmann et al. 2012) and molecular studies still disagree about the genetic identity of T. foetus (Yao \& Köster 2015). Until now, the genetic sequence isolated in the present study may be classified as "cat genotype" like suggested by Slapeta et al. (2010), because this sequence showed the same single nucleotide polymorphism $(\mathrm{T}>\mathrm{C})$ in the ITS2 region. We believe that further studies, with more cats which live exclusively in rural areas may contribute to clarify the epidemiological relationship between $T$. foetus infection in cats and the contact with farm animals.

Co-infection with another parasite was not detected by direct examination of feces in T. foetus positive cats, however, it was found Giardia duodenalis ( $\mathrm{n}=4)$ and C. felis $(\mathrm{n}=1)$ co-infection by PCR. Co-infection with other intestinal parasites, such as Giardia species (Gookin et al. 2004, Bissett et al. 2008, Stockdale et al. 2009, Kingsbury et al. 2010, Köster et al. 2015), Cryptosporidim species (Stockdale et al. 2009), coccidia like Isospora species (Stockdale et al. 2009), Sarcocystes species (Kingsbury et al. 2010), and Toxoplasma gondii (Miró et al. 2011), has been already reported. The most common co-infections are Giardia species and coccidia (Tolbert \& Gookin, 2009). In cats with co-infection by Cryptosporidium species there is an increased severity of diarrhea, and concomitantly increase in the spread of T. foetus (Gookin et al. 2001).

As mentioned before, the diagnosis method is the second point that may interfere with the T. foetus occurrence. The sensitivity of direct examination of feces showed a much lower T. foetus diagnosis than the PCR, as highlighted in previous studies (Gookin et al. 2004, Holliday et al. 2009, Miró et al. 2011, Tysnes et al. 2011). Molecular diagnosis is a good choice mainly in the absence of viable organisms in fecal samples, reducing the false negative diagnosis (Holliday et al. 2009, Doi et al. 2012, Tysnes et al. 2011) and even the false positive diagnosis using other methods such as direct examination of feces and cultivation (Miró et al. 2011). According to the literature, it is difficult to differentiate T. foetus from the Pentatrichomonas 
hominis, a commensal trichomonad of cats, especially by direct examination of feces (Gookin et al. 2007, Yao \& Köster 2015). However, even the PCR may have limitations for diagnosis (Hale et al. 2009). The sensitivity of PCR may be impaired by the degradation of DNA and the presence of inhibitors, similar to what happens with the diagnosis of T. foetus infection in cattle. Fecal samples would be considered a challenge to PCR rightly by the presence of large amounts of inhibitors, such as bilirubin, bile salts, complex carbohydrates, which are often extracted concurrently with the DNA of the pathogen (Gookin et al. 2007). We tried to overcome these limitations through the extraction kit (Stauffer et al. 2008).

Besides, a single fecal sample often results in a false negative diagnosis due to intermittent elimination of the parasite (Thurmond \& Johnson 2004, Hosein et al. 2013). However, repeated sampling was not possible in the present study due to practical limitations, therefore the occurrence of $T$. foetus might be higher.

\section{CONCLUSIONS}

The occurrence of Tritrichomonas foetus was confirmed in cats living in Araçatuba city (Brazil) and also by the genetic sequencing of the parasite.

Although co-infection with other intestinal parasites was observed, T. foetus must be considered as differential diagnosis in cats with diarrhea and also in asymptomatic carriers as source of infection in multi-cat environments.

Acknowledgements.- R.P. Duarte is grateful to Fundação de Amparo à Pesquisa do Estado de São Paulo (FAPESP) for Master's degree scholarship process no. 2014/00243-3. Special thanks to José Eduardo S. Silva for the help with sampling and to Daniel Pricoli Vilela for helping with English translation.

Ethical approval.- All procedures performed in this study were in accordance with ethical standards of the institution, CEUA, FOA/Unesp, process no. 2014-00898.

\section{REFERENCES}

Bell E.T., Gowan R.A., Lingard A.E., McCoy R.J., Slapeta J. \& Malik R. 2010. Naturally occurring Tritrichomonas foetus infections in Australian cats: 38 cases. J. Feline Med. Surg. 12(12):889-898. PMid:20817588. http:// dx.doi.org/10.1016/j.jfms.2010.06.003.

Bissett S., Gowan R., O'brien C., Stone M.R. \& Gookin J.L. 2008. Feline diarrhoea associated with Tritrichomonas cf foetus and Giardia co-infection in an Australian cattery. Aust. Vet. J. 86(11):440-443. PMid:18959533. http:// dx.doi.org/10.1111/j.1751-0813.2008.00356.x.

Bondurant R.H. 1997. Pathogenesis, diagnosis and management of trichomoniasis in catle. Vet. Clin. North. Am. Food. Anim. Pract. 13(2):345-361.

Conraths F.J. \& Schares G. 2006. Validation of molecular-diagnostic techniques in the parasitological laboratory. Vet. Parasitol. 136(2):91-98. PMid:16414191. http://dx.doi.org/10.1016/j.vetpar.2005.12.004.

Dahlgren S.S., Gjerde B. \& Pettersen H.Y. 2007. First record of natural Tritrichomonas foetus infection of the feline uterus. J. Small Anim. Pract. 48(11):654-657. PMid:17725583. http://dx.doi.org/10.1111/j.17485827.2007.00405.x.

Doi J., Hirota J., Morita A., Fukushima K., Kamij Yo H., Ohta H., Yamasaki M., Takahashi T., Katakura K. \& Oku Y. 2012. Intestinal Tritrichomonas suis (=T. foetus) infection in Japanese cats. J. Vet. Med. Sci. 74(4):413-417. PMid:22104396. http://dx.doi.org/10.1292/jvms.11-0171.
Felleisen R.S.J., Lambelet N., Bachmann P., Nicolet J., Müller N. \& Gottstein B. 1998. Detection of Tritrichomonas foetus by PCR and DNA enzyme immunoassay based on rRNA gene unit sequences. J. Clin. Microbiol. 36(2):513-519. PMid:9466768.

Frey C.F., Schild M., Hemphill A., Stünzi P., Müller N., Gottstein B. \& Burgener I.A. 2009. Intestinal Tritrichomonas foetus infection in cats in Switzerland detected by in vitro cultivation and PCR. Parasitol. Res. 104(4):783-788. PMid:18998166. http://dx.doi.org/10.1007/s00436-008-1255-2.

Gookin J.L., Levy M.G., Law J.M., Papich M.G., Poore M.F. \& Breitschwerdt E.B. 2001. Experimental infection of cats with Tritrichomonas foetus. Am. J. Vet. Res. 62(11):1690-1697. PMid:11703009. http://dx.doi.org/10.2460/ ajvr.2001.62.1690.

Gookin J.L., Birkenheuer J.A., Breitschwerdt E.B. \& Levy M.G. 2002. Single-tube nested PCR for detection of Tritrichomonas foetus in feline feces. J. Clin. Microbiol. 40(11):4126-4130. PMid:12409385. http://dx.doi.org/10.1128/ JCM.40.11.4126-4130.2002.

Gookin J.L., Stebbins M.E., Hunt E., Burlone K., Fulton M., Hochel R., Talaat M., Poore M. \& Levy M.G. 2004. Prevalence and risk factors for feline Tritrichomonas foetus and Giardia infection. J. Clin. Microbiol. 42(6):27072710. PMid:15184456. http://dx.doi.org/10.1128/JCM.42.6.2707-2710.2004.

Gookin J.L., Stauffer S.H. \& Levy M.G. 2007. Identification of Pentatrichomonas hominis in feline fecal samples by polymerase chain reaction assay. Vet. Parasitol. 145(1-2):11-15. PMid:17127004. http://dx.doi.org/10.1016/j. vetpar.2006.10.020.

Gruffydd-Jones T., Addie D., Belák S., Boucraut-Baralon C., Egberink H., Frymus T., Hartmann K., Hosie M.J., Lloret A., Lutz H., Marsilio F., Möstl K., Pennisi M.G., Radford A.D., Thiry E., Truyen U. \& Horzinek M. 2013. Tritrichomoniasis in cats: ABCD guidelines on prevention and management. J. Feline Med. Surg. 15(7):647-649. PMid:23813833. http://dx.doi. org/10.1177/1098612X13489231.

Gunn-Moore D.A., McCann T.M., Reed N., Simpson K.E. \& Tennant B. 2007. Prevalence of Tritrichomonas foetus infection in cats with diarrhoea in the UK. J. Feline Med. Surg. 9(3):214-218. PMid:17446107. http://dx.doi. org/10.1016/j.jfms.2007.01.003.

Hale S., Norris J.M. \& Slapeta J. 2009. Prolonged resilience of Tritrichomonas foetus in cat feces at ambient temperature. Vet. Parasitol. 166(1-2):60-65. PMid:19683398. http://dx.doi.org/10.1016/j.vetpar.2009.07.032.

Holliday M., Deni D. \& Gunn-Moore D.A. 2009. Tritrichomonas foetus infection in cats with diarrhoea in a rescue colony in Italy. J. Feline Med. Surg. 11(2):131134. PMid:18774326. http://dx.doi.org/10.1016/j.jfms.2008.06.004.

Homan W.L., Gilsing M., Bentala H., Limper L. \& van Knapen F. 1998. Characterization of Giardia duodenalis by polymerase-chain-reaction fingerprinting. Parasitol. Res. 84(9):707-714. PMid:9766898. http:// dx.doi.org/10.1007/s004360050474.

Hosein A., Kruth S.A., Pearl D.L., Richardson D., Maggs J.C., Peach H.A. \& Peregrine A.S. 2013. Isolation of Tritrichomonas foetus from cats sampled at a cat clinic, cat shows and a humane society in southern Ontario. J. Feline Med. Surg. 15(8):706-711. PMid:23362340. http://dx.doi. org/10.1177/1098612X13475617.

Kingsbury D.D., Marks S.L., Cave N.J. \& Grahn R.A. 2010. Identification of Tritrichomonas foetus and Giardia spp. infection in pedigree show cats in New Zealand. N. Z. Vet. J. 58(1):6-10. PMid:20200569. http://dx.doi.org/ 10.1080/00480169.2010.65054.

Köster L.S., Chow C. \& Yao C. 2015. Trichomonosis in cats with diarrhoea in Hong Kong, China, between 2009 and 2014. JFMS Open Rep. 1(2):2055116915623561. http://dx.doi.org/10.1177/2055116915623561. PMid:28491403.

Kuehner K.A., Marks S.L., Kass P.H., Sauter-Louis C., Grahn R.A., Barutzki D. \& Hartmann K. 2011. Tritrichomonas foetus infection in purebred cats in Germany: Prevalence of clinical signs and the role of co-infection with other enteroparasites. J. Feline Med. Surg. 13(4):251-258. PMid:21288749. http://dx.doi.org/10.1016/j.jfms.2010.12.002. 
Levy M.G., Gookin J.L., Poore M., Birkenheuer A.J., Dyk-Stra M.J. \& Litaker R.W. 2003. Tritrichomonas foetus and not Pentatrichomonas hominis is the etiologic agent of feline trichomonal diarrhea. J. Parasitol. 89(1):99-104. PMid:12659310. http://dx.doi.org/10.1645/0022-3395(2003)089[0099:TF ANPH]2.0.CO;2.

Lim S., Park S., Ahn K., Oh D., Ryu J. \& Shin S. 2010. First report of feline intestinal trichomoniasis caused by Tritrichomonas foetus in Korea. Korean J. Parasitol. 48(3):247-251. PMid:20877505. http://dx.doi.org/10.3347/ kjp.2010.48.3.247.

Miró G., Hernández L., Montoya A., Arranz-Solís D., Dado D., Rojo-Montejo S., Mendoza-Ibarra J.A., Ortega-Mora L.M. \& Pedraza-Díaz S. 2011. First description of naturally acquired Tritrichomonas foetus infection in a Persian cattery in Spain. Parasitol. Res. 109(4):1151-1154. PMid:21509446. http://dx.doi.org/10.1007/s00436-011-2359-7.

Profizi C., Cian A., Meloni D., Hugonnard M., Lambert V., Groud K., Gagnon A., Viscogliosi E. \& Zenner L. 2013. Prevalence of Tritrichomonas foetus infections in French catteries. Vet. Parasitol. 196(1-2):50-55. PMid:23433647. http://dx.doi.org/10.1016/j.vetpar.2013.01.021.

Reinmann K., Müller N., Kuhnert P., Campero C.M., Leitsch D., Hess M., Henning K., Fort M., Muller J., Gottstein B. \& Frey C.F. 2012. Tritrichomonas foetus isolates from cats and cattle show minor genetic differences in unrelated loci ITS-2 and EF-1 $\alpha$. Vet. Parasitol. 185(2-4):138-144. PMid:22000167. http://dx.doi.org/10.1016/j.vetpar.2011.09.032.

Slapeta J., Craig S., Mcdonell D. \& Emery D. 2010. Tritrichomonas foetus from domestic cats and cattle are genetically distinct. Exp. Parasitol. 126(2):209213. PMid:20438726. http://dx.doi.org/10.1016/j.exppara.2010.04.024.

Slapeta J., Muller N., Stack C.M., Walker G., Lew-Tabor A., Tachezy J. \& Frey C.F. 2012. Comparative analysis of Tritrichomonas foetus (Riedmuller, 1928) cat genotype, T. foetus (Riedmuller, 1928) cattle genotype and Tritrichomonas suis (Davaine, 1875) at 10 DNA loci. Int. J. Parasitol. 42(13-14):1143-1149. PMid:23123273. http://dx.doi.org/10.1016/j.ijpara.2012.10.004.

Stauffer S.H., Birkenheuer A.J., Levy M.G., Marr H. \& Gookin J.L. 2008. Evaluation of four DNA extraction methods for the detection of Tritrichomonas foetus in feline stool specimens by polymerase chain reaction. J. Vet. Diagn. Invest. 20(5):639-641. PMid:18776100. http://dx.doi.org/10.1177/10 4063870802000518.

Stockdale H., Rodning S., Givens M., Carpenter D., Lenz S., Spencer J., Dykstra C., Lindsay D. \& Blagburn B. 2007. Experimental infection of cattle with a feline isolate of Tritrichomonas foetus. J. Parasitol. 93(6):1429-1434. PMid:18314690. http://dx.doi.org/10.1645/GE-1305.1.

Stockdale H.D., Dillon A.R., Newton J.C., Bird R.C., Bondurant R.H., Deinnocentes P., Barney S., Bulter J., Land T., Spencer J.A., Lindsay D.S. \& Blagburn B.L. 2008. Experimental infection of cats (Felis catus) with Tritrichomonas foetus isolated from cattle. Vet. Parasitol. 154(1-2):156-161. PMid:18394809. http://dx.doi.org/10.1016/j.vetpar.2008.02.024.
Stockdale H.D., Givens M.D., Dykstra C.C. \& Blagburn B.L. 2009. Tritrichomonas foetus infections in surveyed pet cats. Vet. Parasitol. 160(1-2):13-17. PMid:19070434. http://dx.doi.org/10.1016/j.vetpar.2008.10.091.

Suzuki J., Murata R., Kobayashi S., Sadamasu K., Kai A. \& Takeuchi T. 2011. Risk of human infection with Giardia duodenalis from cats in Japan and genotyping of the isolates to assess the route of infection in cats. Parasitology. 138(4):493-500. PMid:21040620. http://dx.doi.org/10.1017/ S0031182010001459.

Thurmond M.C. \& Johnson W.0. 2004. Effect of multiple sampling on diagnostic sensitivity. J. Vet. Diagn. Invest. 16(3):233-236. PMid:15152840. http:// dx.doi.org/10.1177/104063870401600311.

Tolbert M.K. \& Gookin J. 2009. Tritrichomonas foetus: a new agent of feline diarrhea. Compend. Contin. Educ. Vet. 31(8):374-381, 390, quiz 381. PMid:19866444.

Tysnes K., Gjerde B., Nødtvedt A. \& Skancke E. 2011. A cross-sectional study of Tritrichomonas foetus infection among healthy cats at shows in Norway. Acta Vet. Scand. 53(1):39-45. PMid:21689400. http://dx.doi. org/10.1186/1751-0147-53-39.

Walden H.S., Dykstra C., Dillon A., Rodning S., Givens D., Bird R., Newton J. \& Lindsay D. 2013. A new species of Tritrichomonas (Sarcomastigophora: Trichomonida) from the domestic cat (Felis catus). Parasitol. Res. 112(6):22272235. PMid:23525691. http://dx.doi.org/10.1007/s00436-013-3381-8.

Xenoulis P.G., Saridomichelakis M.N., Read S.A., Suchodolski J.S. \& Steiner J.M. 2010. Detection of Tritrichomonas foetus in cats in Greece. J. Feline Med. Surg. 12(10):831-833. PMid:20674428. http://dx.doi.org/10.1016/j. jfms.2010.05.010.

Xiao L., Escalante L., Yang C., Sulaiman I., Escalante A.A., Montali R.J., Fayer R. \& Lal A.A. 1999a. Phylogenetic analysis of Cryptosporidium parasites based on the small-subunit rRNA gene locus. Appl. Environ. Microbiol. 65(4):1578-1583. PMid:10103253.

Xiao L., Morgan U.M., Limor J., Escalante A., Arrowood M., Shulaw W., Thompson R.C., Fayer R. \& Lal A.A. 1999b. Genetic diversity within Cryptosporidium parvum and related Cryptosporidium species. Appl. Environ. Microbiol. 65(8):3386-3391. PMid:10427023.

Xiao L., Alderisio K., Limor J., Royer M. \& Lal A.A. 2000. Identification of species and sources of Cryptosporidium oocysts in storm waters with a smallsubunit rRNA-based diagnostic and genotyping tool. Appl. Environ. Microbiol. 66(12):5492-5498. PMid:11097935. http://dx.doi.org/10.1128/ AEM.66.12.5492-5498.2000.

Yao C. \& Köster L.S. 2015. Tritrichomonas foetus infection, a causative of chronic diarrhea in the domestic cat. Vet. Res. (Faisalabad) 46:35. http:// dx.doi.org/10.1186/s13567-015-0169-0. 